\title{
АНАЛИЗ ИННОВАЦИОННОЙ АКТИВНОСТИ ОТРАСЛЕЙ САМАРСКОЙ ОБЛАСТИ С ИСПОЛЬЗОВАНИЕМ РЕГИОНАЛЬНОГО ИНДЕКСА ИННОВАЦИЙ
}

\section{ANALYSIS OF INNOVATIVE ACTIVITY OF SAMARA REGION INDUSTRIES USING THE REGIONAL INNOVATION INDEX}

\section{A. Smolkova}

Summary. Innovative activity of industrial enterprises of the Samara region is significant for the development of the entire region. With the help of innovation activity, the nature of the innovation activity is assessed, since all types of production activities, including innovation, are focused on the final result and improving the efficiency of companies. The article is devoted to the analysis of the indicators of the Russian regional innovation index, which reflects the conditions of innovation activity of the regions.

Keywords: industry, region, innovation activity, innovation activity, regional innovation index.

\section{Ввехение}

A ктуальность. В развитии экономической системы важную роль играет развитие инновационного потенциала. Лишь страна с высоким инновационным потенциалом может занимать ведущие позиции на мировой арене. Правительство России оказывает разностороннюю поддержку инновационным предприятиям, стремится развивать инновационную сферу страны. На уровне регионов приняты государственные программы развития данной сферы. Так, в Самарской области Постановлением Правительства утверждена государственная программа «Создание благоприятных условий для инвестиционной и инновационной деятельности Самарской области» на 2014-2030 годы [1].

Изученность проблемы. Изучению проблем в сфере инновационной деятельности и инновационной активности предприятий промышленного комплекса выступают труды отечественных и зарубежных ученых М. Альберта, Б. Андерсена, П. Друкера, Б. Лундвалла, М. Мескона, Р. Нельсона, М. Портера, Ф. Хайека, М. Хаммера, Й. Шумпетера, Ю.П. Анисимова, М.Ю. Архиповой, Н.В. Василенко, С.Ю. Глазьева, В.В.Гольберта, Д.Н. Дударева, Д.И. Кокурина, Н.Д. Кондратьева, В.И. Кушлина, Д.С. Львова, Д.С. Милль, О.С. Ноговициной, Р.С. Петро-
Смолькова Анна Юрьевна

Старший преподаватель, Самарский филиал Московского городского педагогического университета (2. Самара)

smolkovaanna1986@mail.ru

Аннотация. Инновационная активность промышленных предприятий Самарской области является значимой для развития всего региона. С помощью инновационной активности оценивается характер осуществляемой инновационной деятельности, так как все виды производственной деятельности, включая и инновационную, ориентированы на конечный результат и повышение эффективности деятельности компаний. Статья посвящена анализу показателей российского регионального инновационного индекса, который отражает условия инновационной деятельности регионов.

Ключевые слова: отрасль, регион, инновационная активность, инновационная деятельность, региональный инновационный индекс.

ва, А.З. Селезнева, Е.К. Смирницкого, О.Ю. Трилицкой, А.А. Трифиловой, Н.М. Тюкавкина, 5 Р.А. Фатхутдинова, Г.Г. Фетисова, А.Н. Фоломьева, Г.А. Хмелевой, В.М. Шепелева, Ю.В. Яковеца.

Несмотря на значительное число работ, посвященных этому вопросу, снижение реальных показателей и поиск возможностей повышения объемов производства инновационных товаров, работ, услуг в различных регионах остается насущной проблемой.

Для Самарской области это актуальный вопрос, так как в Самарской области сформирован мощный инновационный территориальный аэрокосмический кластер и предприятия кластера реализуют приоритетные государственные задачи по обеспечению обороноспособности страны, подготовки высококвалифицированных кадров, трансфера технологий в другие сферы экономики. Это и определило целесообразность разработки темы.

\section{Цель исслеАования}

Провести анализ инновационной активности промышленности Самарской области с использованием инновационного регионального индекса. 


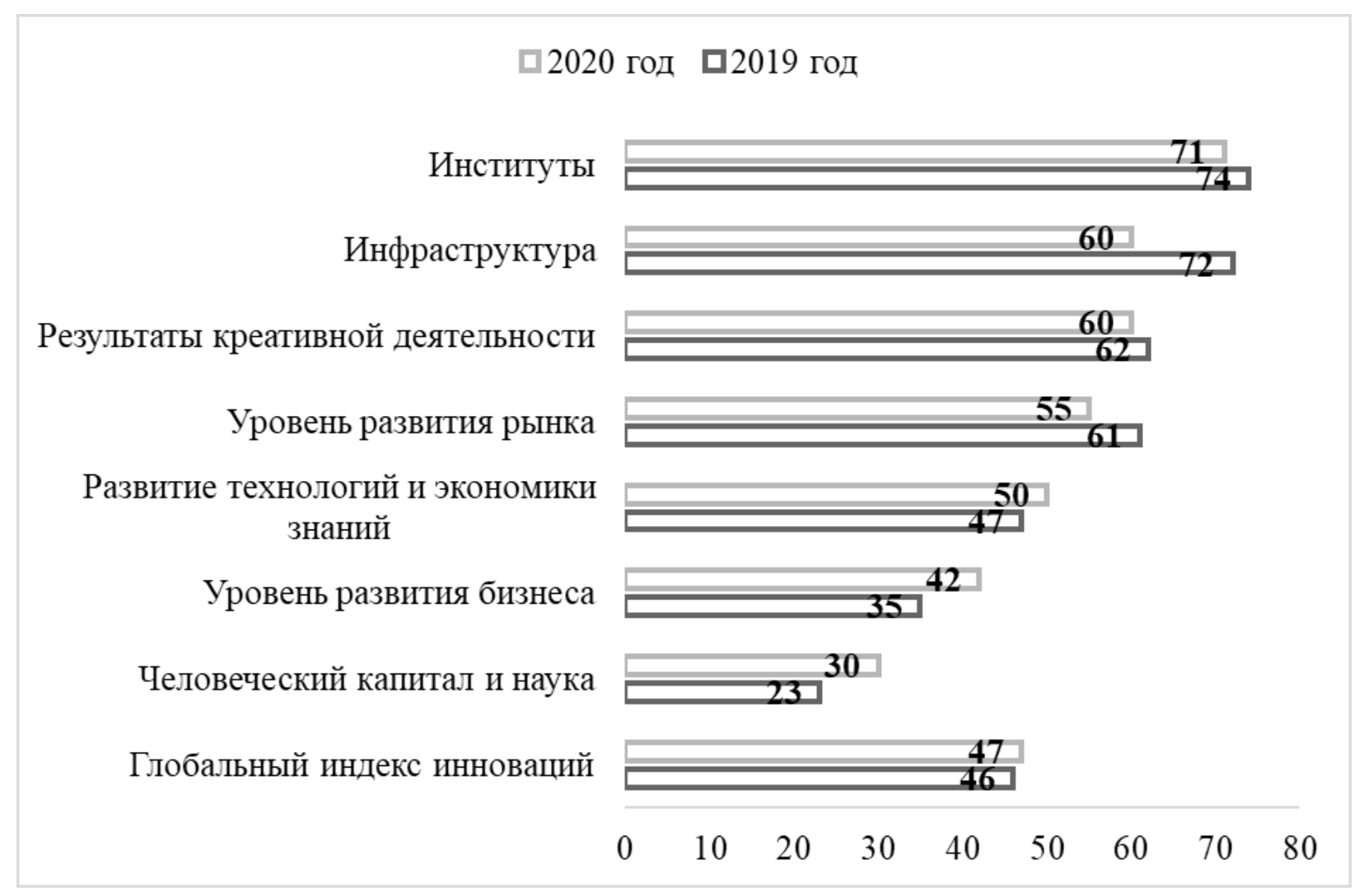

Рис. 1. Место России в рейтинге GII по элементам индекса инноваций

\section{Материалы и метомы}

Теоретической и методологической основой проведенного исследования послужили работы отечественных и зарубежных ученых в области оценки инновационной активности и устойчивости функционирования промышленных предприятий.

В проведенном исследовании использовался статистический инструментарий, системный анализ, а также общенаучные методы (функциональный, сравнительный, структурный, индексный и др.).

\section{Результаты}

Влияние пандемии на деловую активность предприятий промышленности оказалось менее весомым, чем на другие отрасли национальной экономики, т.к. основной объем промышленного производства в стране формируют крупные отраслеобразующие и системообразующие предприятия, которые в той или иной мере получили государственную поддержку в кризисный период, что позволило снизить негативные последствия и не допустить резкого снижения численности занятых, составляющих $20 \%$ от общего количества экономически активного населения [2, с. 4]. Промышленность занимает важное место в экономике Российской Федерации, формируя $27 \%$ валовой добавленной стоимости, в том числе $14 \%$ - за счет обрабатывающих производств.

В структуре валового регионального продукта (ВРП) Самарской области 24\% занимает обрабатывающая промышленность [3], при том, что на 01.01.2020 г. число предприятий и организаций обрабатывающей промышленности в Самарской области составляет 7663 единиц [4], что является 7,8\% общей численности организаций и предприятий Самарской области.

Большую долю в общей численности организаций и предприятий Самарской области занимает отрасль «торговля оптовая и розничная» - 32,5\%, но в структуре ВРП эта отрасль представлена на 14\%.

Активизация инновационной деятельности в промышленном производстве с учетом курса государства на импортозамещение и ликвидацию последствий экономических санкций в отношении РФ со стороны индустриально развитых стран Европы и США способствует технологическому преодолению отставания в развитии инноваций. 
Таблица 1. Рейтинг субъектов Российской Федерации по значению российского регионального инновационного индекса 2019 год

\begin{tabular}{|l|l|l|l|}
\hline Регион & Группа по РРИИ & Ранг по РРИИ & РРИИ \\
\hline Москва & I & 1 & 0,5378 \\
\hline Республика Татарстан & I & 2 & 0,5375 \\
\hline Санкт-Петербург & I & 3 & 0,5356 \\
\hline Томская область & I & 4 & 0,5312 \\
\hline Нижегородская область & I & 5 & 0,4957 \\
\hline$\ldots$ & & & \\
\hline Самарская область & I & 11 & 0,4167 \\
\hline$\ldots$ & & & 0,1214 \\
\hline Чукотский автономный округ & IV & 85 & \\
\hline
\end{tabular}

Таблица 2. Рейтинг субъектов Российской Федерации по значению индекса инновационной деятельности

\begin{tabular}{|c|c|c|c|}
\hline Регион & Группа по ИИД & Ранг по ИИД & иид \\
\hline Республика Татарстан & 1 & 1 & 0,5702 \\
\hline Чувашская республика & 1 & 2 & 0,5439 \\
\hline Санкт-Петербург & 1 & 3 & 0,5125 \\
\hline Томская область & 1 & 4 & 0,5050 \\
\hline Республика Мордовия & 1 & 5 & 0,5050 \\
\hline \multicolumn{4}{|l|}{$\ldots$} \\
\hline Самарская область & III & 39 & 0,2684 \\
\hline$\ldots$ & & & \\
\hline Республика Ингушетия & IV & 85 & 0,0271 \\
\hline
\end{tabular}

Инновационный потенциал предприятий России не реализован в полной мере. На мировой арене по показателю глобального индекса инноваций в 2020 году Россия находится на 47 месте, опустившись на один пункт по сравнению с прошлым годом. С 2016 года этот показатель имеет тенденцию снижения.

Глобальный индекс инноваций (The Global Innovation Index) - глобальное исследование и сопровождающий его рейтинг стран мира по показателю развития инноваций по версии международной бизнес-школы INSEAD [5].

Позиция России по субиндексу ресурсы инноваций традиционно оказалась значительно выше, чем по субиндексу инновационный выпуск (42-е место против 58-го).

На рисунке 1 представлены позиции России по элементам индекса инноваций в GII 2020 г. по сравнению с показателями 2019 г.
В сфере инноваций Россия занимает 6-е место среди стран с уровнем дохода выше среднего, в 2019 году Россия занимала 3-е место среди стран со средним уровнем дохода [6].

По данным Высшей школы экономики и Института статистических исследований и экономики знаний, рейтинг Самарской области по значению российского регионального инновационного индекса (РРИИ) составляет 11 место из 85. Самарская область входит во ІІ группу рейтинга (табл. 1).

В расчете рейтинга инновационного развития регионов отражаются социально-экономические условия инновационной деятельности регионов, их научно-технический потенциал, уровень инновационной и экспортной активности, а также качество инновационной политики.

Самарская область по значению российского регионального инновационного индекса улучшила свои позиции с 20 места в 2017 г. [7] до 11 места в 2019 г. 
Таблица 3. Рейтинг субъектов Российской Федерации по значению индекса социальноэкономических условий инновационной деятельности

\begin{tabular}{|l|l|l|l|}
\hline Регион & Группа по ИСэуид & Ранг по ИСэуид & ИСэуид \\
\hline Москва & I & 1 & 0,5519 \\
\hline Республика Татарстан & I & 2 & 0,5234 \\
\hline Санкт-Петербург & I & 3 & 0,5191 \\
\hline Томская область & I & 4 & 0,5190 \\
\hline Самарская область & I & 5 & 0,4904 \\
\hline$\ldots$ & & & \\
\hline Республика Дагестан & IV & 85 & 0,2407 \\
\hline
\end{tabular}

Таблица 4. Рейтинг субъектов Российской Федерации по значению индекса качества инновационной политики

\begin{tabular}{|l|l|l|l|}
\hline Регион & Группа по ИКИП & Ранг по ИкиП & ИкиП \\
\hline Республика Татарстан & I & 1 & 0,6424 \\
\hline Москва & I & 2 & 0,5862 \\
\hline Новосибирская область & I & 3 & 0,5824 \\
\hline Томская область & I & 4 & 0,5791 \\
\hline Калужская область & I & 5 & 0,5631 \\
\hline$\ldots$ & & & 0,5175 \\
\hline Самарская область & I & 10 & \\
\hline$\ldots$ & & & 0,0009 \\
\hline Чукотский автономный округ & IV & 85 & \\
\hline
\end{tabular}

Индекс инновационной деятельности (ИИД) оценивает интенсивность процессов создания, внедрения и практического использования в регионе технологических, маркетинговых и организационных инноваций. ИИД отражает четыре основные направления: активность в сфере инноваций, малый инновационный бизнес, затраты на технологические инновации и результативность инновационной деятельности (табл. 2).

Наиболее успешно инновационная деятельность реализуется в крупных экономически развитых центрах страны, более половины из которых представляют Приволжский федеральный округ. Причем, у Самарской области по значению индекса инновационной деятельности достаточно низкий показатель- 39 место и 3 группа классификации. В 2019 году данный показатель значительно ухудшился по сравнению с показателем 2017 года. Так, в 2017 году Самарская область занимала 19 место (II группа). Не смотря на низкие показатели ИИД, Самарская область входит в пятерку рейтинга социально-экономических условий инновационной деятельности (табл. 3).

Рейтинг субъектов Российской Федерации по индексу социально-экономических условий инновационной деятельности (ИСЭУИД) представляет оценку их экономического, образовательного и цифрового развития, демонстрирующую потенциал к созданию, адаптации, освоению и реализации инноваций [8].

Данный индекс отражает три основных направления: основные макроэкономические показатели, образовательный потенциал населения и потенциал цифровизации.

В 2019 году Самарская область улучшила свои позиции по рейтингу индекса социально-экономических условий инновационной деятельности до 5 места вместо 6 места в 2017 году.

Также Самарская область входит в первую группу рейтинга по качеству инновационной политики и занимает 10 место против 39 места в 2017 году (III группа) (табл. 4). Этот индекс отражает четыре основных тематические рубрики: нормативная правовая база инновационной политики, организационное обеспечение инновационной политики, бюджетные затраты на науку и инновации и участие в федеральной научно-технической и инновационной политике. 
Не смотря на стремительный рост объема инновационных товаров, работ и услуг в Российской Федерации и в Приволжском федеральном округе за период с 2010 по 2018 гг., в Самарской области наблюдается рост показателя с 2010 по 2015 гг., а с 2016 года данный показатель ежегодно снижается. Так к 2019 году по сравнению с наивысшим показателем в 2015 году, объем инновационных товаров, работ и услуг снизился на $29,2 \%$.

С 2015 г. доли инновационных товаров, работ, услуг от общего показателя отгруженных товаров работ, услуг по Самарской области стойко снижаются.

\section{Зак^ючение}

В результате анализа выявлено, что с 2016 года наблюдается ежегодное снижение показателей уровня инновационной активности организаций Самарской области, не смотря на разностороннюю поддержку государства.

В дальнейших исследованиях по теме необходимо определить причины снижения объемов инновационных, товаров, работ, услуг в Самарской области при достаточно высоком в ПФО уровне затрат на инновационную деятельность.

\section{ЛИТЕРАТУРА}

1. Смолькова А.Ю. Рейтинг России в глобальном инновационном индексе в 2019 году // Актуальные проблемы и тенденции развития современной экономики: материалы международной научно-практической конференции 18-19 ноября 2019 г.: в 2 ч. Самара: Самар. гос. техн. ун-т, 2019. С. 62-66.

2. Деловой климат в промышленности в августе 2020 г.- М.: НИУ ВШЭ, 2020.— С. 4.

3. Инновационный территориальный аэрокосмический кластер. [Электронный ресурc] URL: http://cik63.ru/uslugi-centra/o-centre/aerospace-cluster/ (дата обращения 25.09.2021).

4. Предприятия и организации. Самарский статистический ежегодник. 2020: P13 Стат. сб. [Электронный ресурс] / Самарастат. С., 2020. URL: https:// samarastat.gks.ru/organizations (дата обращения: 21.10.2021).

5. Глобальный индекс инноваций. Гуманитарная энциклопедия: Исследования // Центр гуманитарных технологий, 2006-2019. [Электронный ресурc].— URL: https://gtmarket.ru/ratings/global-innovation-index/info (дата обращения 30.06.2021 г.).

6. Глобальный инновационный индекс 2020 года. Главные выводы. [Электронный ресурс]. — URL: https://www.wipo.int/edocs/pubdocs/ru/wipo_pub_ gii_2020_keyfindings.pdf (дата обращения 17.08.2021 г.).

7. Смолькова А.Ю., Сураева М.О. Инновационное развитие Самарской области и проблемы региональных вузов // Российские регионы как центры развития в современном социокультурном пространстве: сборник научных статей материалы 5-й Всероссийской науч.-практ. конф. Юго-Зап. гос. ун-т. Курск, 2019. С. 305-311.

8. Рейтинг социально-экономических условий инновационной деятельности. Национальный исследовательский университет «Высшая школа экономики». [Электронный ресурс].— URL: https://region.hse.ru/rankingse19. (дата обращения 17.08.2021 г.).

(с Смолькова Анна Юрьевна ( smolkovaanna1986@mail.ru ).

Журнал «Современная наука: актуальные проблемы теории и практики» 